\title{
A conceptual model of the hydrological influence of fissures on landslide activity
}

\author{
D. M. Krzeminska ${ }^{1}$, T. A. Bogaard ${ }^{1}$, Th. W. J. van Asch $^{2}$, and L. P. H. van Beek ${ }^{2}$ \\ ${ }^{1}$ Department of Water Management, Delft University of Technology, P.O. Box 5048, 2600 GA, Delft, The Netherlands \\ ${ }^{2}$ Department of Physical Geography, Utrecht University, UCEL, P.O. Box 80115, 3508 TC, Utrecht, The Netherlands
}

Correspondence to: D. M. Krzeminska (d.m.krzeminska@tudelft.nl)

Received: 24 November 2011 - Published in Hydrol. Earth Syst. Sci. Discuss.: 13 December 2011

Revised: 10 May 2012 - Accepted: 15 May 2012 - Published: 1 June 2012

\begin{abstract}
Hydrological processes control the behaviour of many unstable slopes, and their importance for landslide activity is generally accepted. The presence of fissures influences the storage capacity of a soil and affects the infiltration processes of rainfall. The effectiveness of the fissure network depends upon fissure size, their spatial distribution, and connectivity. Moreover, fissure connectivity is a dynamic characteristic, depending on the degree of saturation of the medium.

This research aims to investigate the influence of the fissure network on hydrological responses of a landslide. Special attention is given to spatial and temporal variations in fissure connectivity, which makes fissures act both as preferential flow paths for deep infiltration (disconnected fissures) and as lateral groundwater drains (connected fissures). To this end, the hydrological processes that control the exchange of water between the fissure network and the matrix have been included in a spatially distributed hydrological and slope stability model. The ensuing feedbacks in landslide hydrology were explored by running the model with one year of meteorological forcing. The effect of dynamic fissure connectivity was evaluated by comparing simulations with static fissure patterns to simulations in which these patterns change as a function of soil saturation. The results highlight that fissure connectivity and fissure permeability control the water distribution within landslides. Making the fissure connectivity function of soil moisture results in composite behaviour spanning the above end members and introduces stronger seasonality of the hydrological responses.
\end{abstract}

\section{Introduction}

\subsection{Motivation and objective}

Hydrology has long been recognized as a crucial factor in initiation and reactivation of landslides. Generally, the internal strength of the slope decreases as the groundwater level rises and pore pressure increases. The unsaturated zone controls groundwater recharge allowing for the loss of soil moisture by evaporation and attenuation of percolation. It also provides preferential flow paths (formed by soil fauna, by plant roots, soil erosion, etc; Beven and Germann, 1982) for infiltration (Bogaard and Van Asch, 2002; Krzeminska et al., 2011). Additionally, in slow-moving landslides, continuous movement of the sliding material results in fissure formation due to compression and extension. These fissures can act both as preferential flow paths for infiltration and as lateral groundwater drains. As such, they have strong influence on groundwater level fluctuation and thus on slope stability.

The main aim of this research is to study the importance of preferential fissure flow for landslide hydrological behaviour and slope stability at the field scale. The conceptual model was based on the Storage and Redistribution of Water on Agricultural and Re-vegetated Slopes model (STARWARS), which is a distributed model coupling hydrological and stability dynamics (Van Beek, 2002). 


\subsection{Preferential fissure flow and its relevance for landslide hydrology}

Macropores are defined as structural pores that are much larger than the average soil matrix pores (Beven and Germann, 1982) and drain mainly by gravitational forces (not influenced by capillarity). Fissures are a special case of macropores with apertures that vary from a few, up to tens of centimetres. For the purpose of this study, we will use the term "fissures" to refer to geo-mechanically induced cracks that are filled or partly filled with reworked material. Accordingly, we use the term "preferential fissure flow" to refer to rapid water flow in fissures bypassing the bulk of the less pervious matrix (Beven and Germann, 1982).

The importance of macropore flow for slope hydrology (including slope stability) was recognised in the early 1980s (Pierson, 1983; Brand et al., 1986) and has subsequently been receiving a great deal of research attention (Tsuboyama et al., 1994; Noguchi et al., 1999; Nobles et al., 2004; Nieber and Sidle, 2004).Various authors reported adverse and beneficial effects of macropore flow (including fissure flow) on landslide activity (McDonnell, 1990; Van Beek and Van Asch, 1999; Fannin et al., 2000; Uchida et al., 2001).The presence of fissures can lead to slope instability by influencing the soil water storage capacity and by affecting the infiltration processes of rainfall. Fast flow through the fissures may increase the rate of vertical infiltration, providing direct access to the lower groundwater and increasing the rate of groundwater recharge. On the other hand, an extended fissure network may increase the rate of natural soil drainage, which limits the build up of water pressure. However, when dead-end fissures are present (a disconnected fissure network), once their storage capacity is exceeded, they contribute to maintaining high pore water pressures in the surrounding soils (McDonnell, 1990; Van Asch et al., 1996; Uchida et al., 2001; Krzeminska et al., 2009).

Initiation of macropore flow depends mainly on antecedent soil moisture content, rainfall amount and intensity, hydraulic conductivity of the soil matrix, density and distribution of macropores and soil texture (Bouma, 1990; Trojan and Linden, 1992; Weiler and Naef, 2003). The macropore flow can be initiated either at the soil surface or from (partially-) saturated soil layer, when the rainfall or percolation intensity exceeds the infiltration rate of the lower soil layer. The interaction between macropores and the surrounding soil-matrix depends on soil matrix properties, soil water content and the properties of macropores and matrixmacropore interface (Weiler and Naef, 2003).

The effectiveness of macropores (fissures) for transmitting water downslope depends upon their size, spatial distribution, and connectivity (Beven and Germann, 1982; McDonnell, 1990; Cameira et al., 2000; Nobles et al., 2004). The larger the macropores are, the more water they can potentially conduct or store, depending on the connectivity between macropores. The macropores themselves are not considered to be continuous throughout the soil profile or the hillslope. It is more likely that they are separated by matrix stretches located at the endpoints of the individual macropores (e.g. Noguchi et al., 1999; Sidle et al., 2001). In this way, the macropore connectivity depends on the water content in the separating matrix stretches, and the degree of macropore effectiveness increases with wetness (Tsuboyama et al., 1994; Sidle et al., 2000). However, despite field evidence, laboratory experiments and analytical research, the relationship between soil moisture and macropore connectivity is qualitative only (Nieber and Sidle, 2004) and its quantification remains difficult.

The complexity of the preferential flow processes, and their high spatial and temporal variability, makes it very difficult to measure the processes in the field and to upscale the information to the catchment scale (Van Asch et al., 2007; Van Schaik, 2009). In a slow-moving landslide, continuous movement of the sliding material and its heterogeneity make the system of preferential fissure flow paths difficult to characterise. Moreover, constant opening and closing of the aperture in the reworking material makes it even more difficult to monitor and model preferential fissure flow.

\subsection{Preferential flow in landslide hydrological modelling}

To analyse rainfall-induced landsliding, governed by either unsaturated or saturated conditions, several models were proposed (Wu and Sidle, 1995; Van Beek and Van Asch, 1999; Iverson, 2000; Brooks et al., 2002; Cappa et al., 2004). Numerical codes vary from simple 1-D lumped models to complex physically based 3-D models and can involve either traditional (area-averaged values of equivalent parameters) or distributed approaches. Distributed approaches are the most suitable to account for spatial and temporal heterogeneity of the hydrological systems (e.g. Miller and Sias, 1998), and thus, they improve forecasting of spatio-temporal probabilities of landslides (Malet et al., 2005; Van Westen et al., 2005).

Incorporating preferential flow modelling into a hillslopescale hydrological model is difficult due to the complexity of the phenomenon. At the field scale, the majority of macropore flow models use deterministic methods to study water transport (Van Schaik, 2010). Preferential flow is often modelled indirectly as a simplified system with preferential vertical fluxes (Bogaard, 2002) or rapid slope-parallel flow on the bedrock surface without taking into account the distributed nature of the soil macropores system (Beckers and Alila, 2004; Kosugi et al., 2004). Moreover, in many largescale models, preferential flow is included as a modification of the hydraulic conductivity function (e.g. Mulungu et al., 2005; Zhang et al., 2006). Zehe and Blöschl (2004) used a threshold function to switch on macropore flow and established a linear increase of the hydraulic conductivity, with increasing relative saturation of the soil for both plot- and 
catchment-scale hydrological modelling. Weiler and McDonnell (2007) stressed that conceptualization and parameterization of the effect of lateral preferential flow on hillslope hydrology is one of the great challenges. They attempt to combine the quantitative and qualitative approach, to incorporate the spatially dynamic nature of preferential flow systems, by bringing lateral preferential flow into a formal model structure as randomly generated pipe network.

In 1999, Van Beek and Van Asch proposed conceptual hillslope model that accounts for fissure-induced infiltration. This is a spatially distributed physically based model, coupling hydrological and stability dynamics, developed in the PCRaster GIS. The use of this meta-language provides an expedient way to include and change spatially distributed hydrological and geotechnical parameters. In the subsequent development of the STARWARS model, fissure flow was accounted for in a simpler manner, allowing a fraction of the surface detention, equal the volume of free pore space (i.e. fissures), to bypass the unsaturated matrix and directly recharge the groundwater.

Since its development, the STARWARS model has been used by many researchers to study different hydrological and ecological issues for both synthetic and real case studies (Van Beek, 2002; Malet et al., 2005; Kuriakose et al., 2009; Brolsma, 2010). In 2005, Malet and co-authors applied the STARWARS model to the Super-Sauze landslide using the simple bypass flow scheme representing only shallow bypassing flow without fissure-matrix interaction (Fig. 2a). They concluded that accounting for fissure flow was an important improvement in modelling the hydrology of the landslide and stressed a need for further specific research on this topic.

\section{Adaptation of STARWARS}

\subsection{General model description}

Here, we build on the original version of STARWARS model (Van Beek, 2002) by including a more detailed representation of fissure flow by including and expanding the original conceptualization of Van Beek and Van Asch (1999). The STARWARS model consists of a core model resolving dynamic equations of saturated and unsaturated flow and of sub-models that describe specific hydrological processes, such as interception, transpiration, snow cover or snow melt (Fig. 1).

The model represents the soil mantle (as a column of three layers) overlying a semi-impervious bedrock. The layers have variable depth, centred on the mid-point or node of each cell of an equidistant grid in the $x$ - and $y$-direction. The hydrological model describes the saturated $\left(Q_{\text {sat }}\right)$ and the unsaturated $(\mathrm{Pe})$ transient flow as a function of gravitational potential only, assuming freely drainable water (unconfined groundwater levels). Precipitation $(P)$ and evaporation $(E)$ constitute the boundary condition at the top of the soil column. The percolation loss across the lithic contact into the underlying bedrock reservoir constitutes the lower boundary condition (BC). For a complete description of the model, the reader is referred to Van Beek (2002).

Within each model time step, all the calculations of particular processes within each soil column are ordered as follows: reading the initial conditions (water level and soil moisture content in the matrix and in the fissures), evaluating upper and lower boundary conditions, the calculation of vertical fluxes, updating the storages, the evaluation of lateral fluxes and updating the storages, which set new initial conditions for the next step. Although each soil column has a certain storage volume to accommodate the unsaturated and saturated fluxes, all fluxes are calculated between nodes.

At the end of each model run, the factor of safety $\left(f_{\mathrm{s}}\right)$ is calculated as the ratio between maximum shearing resistance to failure and shear stress. The infinite slope model is used to calculate slope stability (Skempton, 1964):

$$
f_{\mathrm{s}}=\frac{c+(\sigma-u) \tan \phi}{\frac{W_{\text {fis }}+W_{\text {mat }}}{\Delta x^{2}} \sin \beta \cos \beta}
$$

where $c$ is cohesion, $\sigma$ is total normal stress, $u$ is pore pressure and $\phi$ is the angle of internal friction. $W_{\text {fis }}$ and $W_{\text {mat }}$ are the weight of the fissure and matrix fraction of the cell and $\beta$ is the slope angle. The normal stress is given by

$$
\sigma=\frac{W_{\text {fis }}+W_{\text {mat }}}{\Delta x^{2}} \cos ^{2} \beta,
$$

and the pore pressure is given by

$u=F_{\text {fis }} h_{\mathrm{w}, \text { fis }} \gamma_{\mathrm{w}} \cos ^{2} \beta+\left(1-F_{\text {fis }}\right) h_{\mathrm{w}, \text { mat }} \gamma_{\mathrm{w}} \cos ^{2} \beta$

where $h_{\mathrm{w}, \mathrm{fis} / \mathrm{mat}}$ represents the groundwater height above the shear surface within fissure and matrix fraction respectively, and $\gamma_{\mathrm{w}}$ is the density of the water.

The interaction between cells is neglected, and the calculated stability is dependent on the local cell attributes only. The model uses the soil mantle schematisation shown in Fig. $2 b$, and the lithic contact is assumed to be the potential shear surface. In this way, $f_{\mathrm{s}}$ serves here as a proxy for the excess shear stress that cannot be accommodated by a particular soil column.

\subsection{Representation of fissures}

Our concept of fissure flow is based on the dual-permeability approach (Gerke, 2006; S̆imúnek et al., 2003; Jarvis, 2007). The appearance of fissures creates a system consisting of two overlapping and interacting domains: the fractures and the matrix blocks, which have their own characteristic and properties (i.e. porosity, hydraulic conductivity). Moreover, water flow is allowed in both domains (matrix and fissure).

The explicit inclusion of fissures in STARWARS required an adaptation of the existing model concept (Fig. 2b).The 


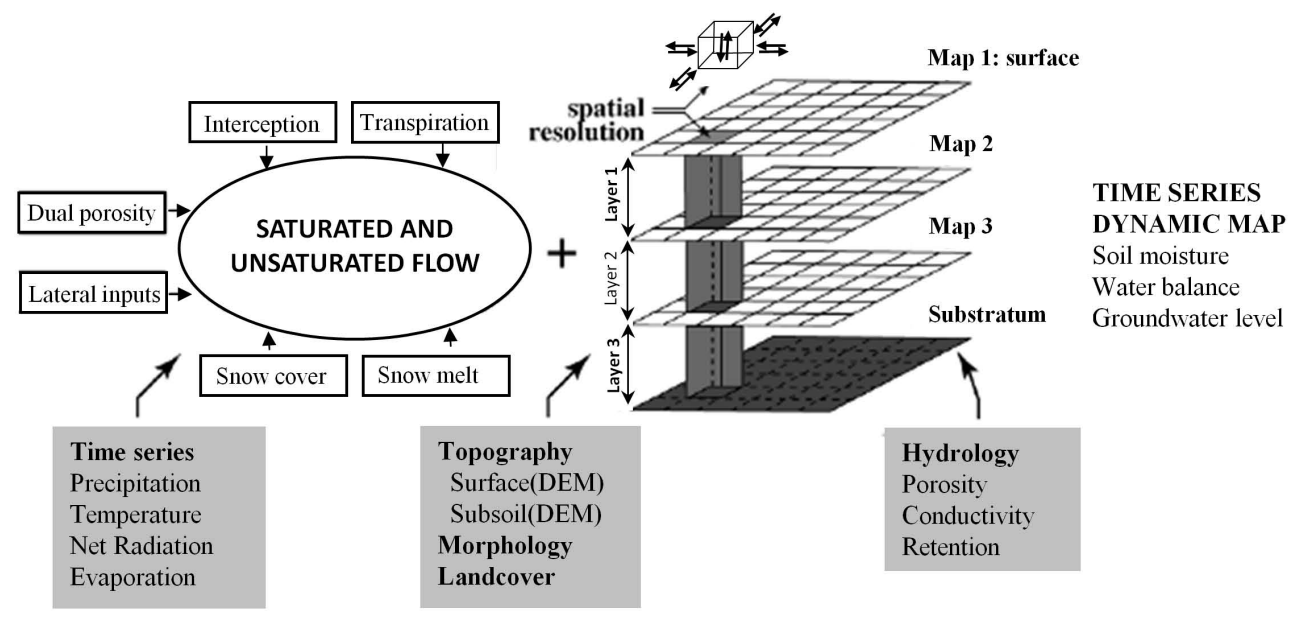

Fig. 1. Architecture of STARWARS model (core model and sub-models) and schematic representation of the model implementation (adapted from Malet et al., 2005, based on Van Beek, 2002)
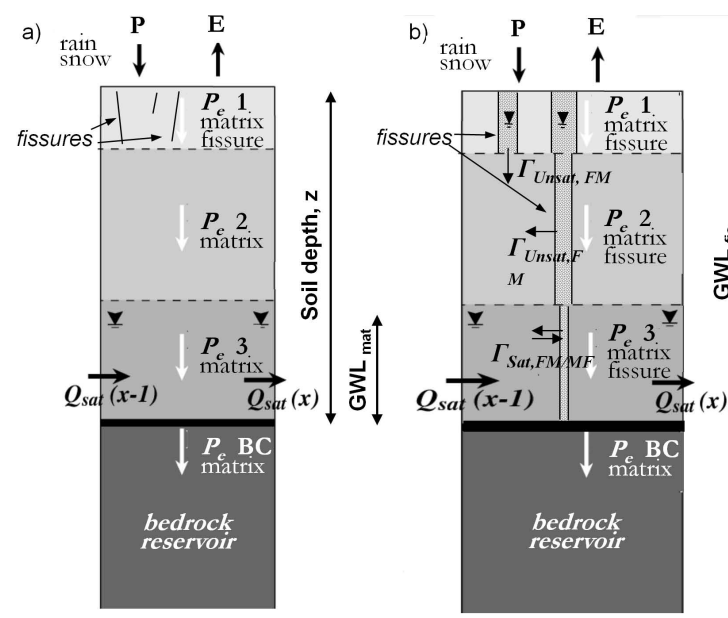

c)

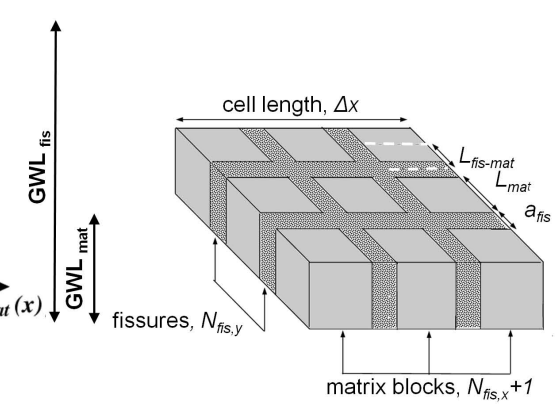

Fig. 2. Schematisation of (a) the original hydrological model (Van Beek, 2002, after Van Beek, 2002; Malet et al., 2005), (b) the hydrological model implemented with this research and (c) fissure representation in the single layer of the soil column.

new concept assumes that fissures are distinct from the matrix and are represented within each cell as a continuous network of highly pervious zones surrounded by matrix blocks (after Van Beek and Van Asch, 1999). For each layer of the soil column, the fissure distribution is prescribed by the fraction of the surface area covered by fissures $\left(F_{\text {fis }}\left[\mathrm{m}^{2} \mathrm{~m}^{-2}\right]\right)$, and mean fissure aperture $\left(a_{\mathrm{fis}}[\mathrm{m}]\right)$. They are distributed evenly throughout the cell (in both $x$ - and $y$-direction), and they extend vertically over the full depth of a particular layer (Fig. 2c). The model allows for defining the fissure fraction and its aperture per cell and per layer. Fissure contents can vary from cell to cell and from layer to layer. The only limitation is that fissures are fully connected vertically, across layers. Additionally, it is possible that fissures will terminate in the first (top) or second layer and not extend entirely to the bottom.
Moreover, field survey showed that the majority of fissures are partly (re-)filled with landslide material, and thus no continuous open fissures are observed. Therefore, in the model we consider that fissures are filled with reworked material and that they retain their own water level and soil moisture content. It is important to keep in mind that the fissure characteristics (i.e. porosity, saturated hydraulic conductivity), as all such input parameters in the model, can be spatially distributed.

The number of fissures per cell is calculated as

$N_{\text {fis }, x}=N_{\text {fis }, y}=\left(1-\sqrt{1-F_{\text {fis }}}\right) \frac{\Delta x}{a_{\text {fis }}}$

where $\Delta x$ is the cell length $[\mathrm{m}]$ and the fissures are assumed to extend over the full length of the cell. $N_{\text {fis }, x}\left(=N_{\text {fis }, y}\right)$ is the number of fissures in $x(=y)$ direction, rounded down to the nearest whole number with a minimum value of 1 if $a_{\mathrm{fis}}>0$. 
In that case, the fractional area covered by fissures is reset to the area of $\left(2 a_{\mathrm{fis}} \Delta x-a_{\mathrm{fis}}^{2}\right) / \Delta x^{2}$. The distance between the fissures equals the width of the matrix blocks. It is assumed that in a cell all fissures are contained by matrix, and thus there are $N_{\text {fis }}+1$ matrix blocks (looking at the $x$-direction) of width $L_{\text {mat }}[\mathrm{m}]$ :

$L_{\text {mat }}=\sqrt{1-F_{\text {fis }}} \frac{\Delta x}{N_{\text {fis }, x}+1}$.

The distance from the centre of a fissure to the centre of each matrix block that defines the different gradients is consequently given by

$L_{\text {mat }- \text { fis }}=\frac{1}{2}\left(L_{\text {mat }}+a_{\text {fis }}\right)$.

\subsection{Adaptation of flux calculations}

\subsubsection{Fluxes within single soil column}

Following the original process description of the STARWARS model (Van Beek, 2002), the unsaturated flow, both in the matrix and fissure domain, is gravitational and vertical only. Percolation is passed on vertically between the layers of the soil column and is controlled by the unsaturated hydraulic conductivity of matrix and fissure domain respectively. The soil water retention curve is described by Farrel and Larson (1972):

$\Theta_{\mathrm{E}, \mathrm{mat} / \mathrm{fis}}=1-\frac{1}{\alpha_{\mathrm{mat} / \mathrm{fis}}} \ln \frac{\left|h_{\mathrm{mat} / \mathrm{fis}}\right|}{h_{\mathrm{A}, \mathrm{mat} / \mathrm{fis}}}$

where $|h|$ is the absolute suction [m], $h_{\mathrm{A}}$ is the air entry value [m], and $\alpha$ is the shape factor [-]. If $|h|$ is less or equal to $h_{\mathrm{A}}$, the soil remains saturated throughout.

The corresponding relationship for the relative unsaturated hydraulic conductivity $\left(k_{\mathrm{r}}[-]\right)$ of Millington and Quirk (1959):

$k_{\mathrm{r}}\left(\Theta_{\mathrm{E}}\right)=\Theta_{\mathrm{E}}^{\tau} \frac{\exp 2 \alpha \Theta_{\mathrm{E}}-2 \alpha \Theta_{\mathrm{E}}-1}{\exp 2 \alpha-2 \alpha-1}$

where $\tau$ is the tortuosity parameter and is set to $4 / 3$ [-]. This equation is applied to calculate unsaturated hydraulic conductivity of both matrices $\left(k_{\mathrm{r}, \mathrm{mat}}\right)$ and fissures $\left(k_{\mathrm{r}, \mathrm{fis}}\right)$.

When the percolation flux in the lowest layer exceeds the basal loss, a groundwater table is formed and it rises upward with the assumption that it is vertically contiguous (for both matrix and fissure fraction).

Surface fluxes (infiltration and evaporation) are partitioned on the basis of the respective surface area $A\left[\mathrm{~m}^{2}\right]$, calculated as $A_{\text {fis }}=F_{\text {fis }} \Delta x^{2}$ for fissure fraction and $A_{\text {mat }}=\left(1-F_{\text {fis }}\right) \Delta x^{2}$ for matrix fraction. Fissures can be recharged directly by rain or snow melt, or indirectly by overland flow.

The storage capacity of a single cell is the combination of matrix and fissure fraction capacity. The infiltration capacity of the fissure fraction network is not limited a priori, meaning that any water that cannot infiltrate into the matrix is passed on to the fissure network. When, after calculating all the fluxes (percolation and lateral exchange), the water storage in the fissures exceeds their capacity, it is returned to the surface as overland flow. Any water remaining as surface detention is redistributed instantaneously as overland flow over the slope.

Lateral exchange $\Gamma\left[\mathrm{m}^{3} \mathrm{~h}^{-1}\right]$ within the cell is possible only between the saturated zones of matrix and fissure fractions $\left(\Gamma_{\mathrm{Sat}, \mathrm{FM} / \mathrm{MF}}\right)$, and the unsaturated zones of the matrix fraction and the saturated zone of the fissure fraction $\left(\Gamma_{\text {Unsat,FM }}\right)$, when water level in the fissure fraction exceeds that found in the matrix fraction. No lateral fluxes occur between the unsaturated zone of the fissure network and unsaturated matrix. However, fissures can drain vertically into the soil when they terminate above the lithic contact.

\subsubsection{Fluxes between soil columns}

Lateral flow $\left(Q_{\text {sat }}\right)$ between the cells occurs across the saturated zone only as result of differences in total piezometric head between the adjacent nodes in the $x$ - and $y$-direction. The total head in each column is comprised of the gravitational potential, the elevation of the bottom of the soil column, and the average of the water level in both the fissure network and matrix, weighed by the respective surface area. The specific discharge across the cell boundaries in the $x$ and $y$-direction depends on the transmissivity in those directions. Transmissivity per domain is the product of saturated permeability (matrix or fissure), water height (in matrix or fissure) and width (matrix width or fissure width in cell). The fissure connectivity $\left(C_{\text {fis }}\right)$ represents the chance for fissure network to be connected laterally between the adjacent soil columns and modifies the transmissivity towards that of the fissure network rather than that of the - less permeable - matrix. As such, there is no explicit "fissure to fissure" in adjacent cell exchange of groundwater. Rather, the total saturated lateral flux is subsequently distributed over the matrix and fissure domains on basis of the ratio of the transmissivity values within a column and the connectivity between fissures.

Although field studies have shown that the macropore continuity is dynamic and positively related to the increase in water content (e.g. Tsuboyama et al., 1994; Sidle et al., 2000; Van Schaik et al., 2008), quantification of this relationship remains difficult. Moreover, there is no research on macropore continuity dedicated particularly to fissures.

In order to elaborate on the dynamic nature of fissure connectivity, we have made the fissure connectivity term $\left(C_{\text {fis }}\right)$ dependent on the soil moisture content of the soil column. In this way we conceptualize that the water exchange between soil columns (lateral flow, $Q_{\text {sat }}$ ) will increase with a rising degree of saturation in the soil column. This shifts the conceptual notion of fissure connectivity from the geometric property of fissure network towards a dynamic aspect of the combined hydrology of heavily fissured soil. In analogy 


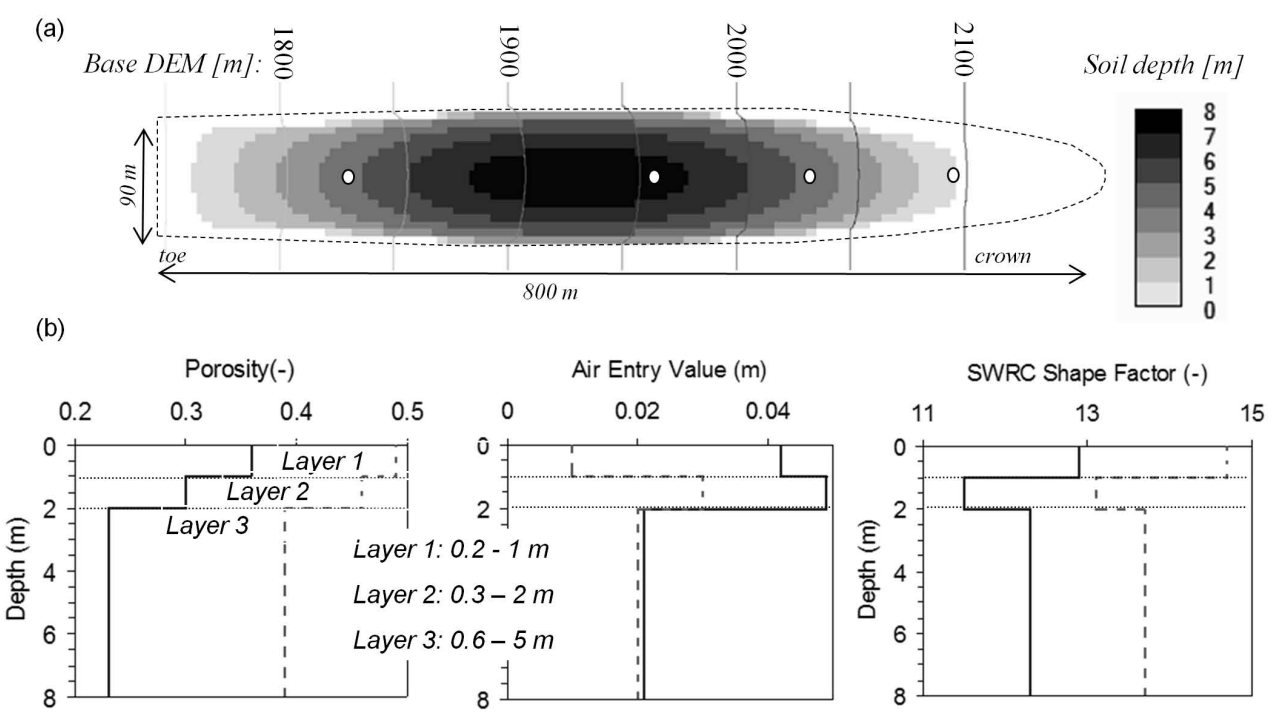

Fig. 3. (a) Geometry of the idealised, "simple" landslide representation; the contour lines show the DEM of the bedrock and the white dots indicate the points for which the groundwater level fluctuation are reported (see Fig. 9). (b) Matrix (solid line) and fissure (broken line) properties.

to macropore flow (e.g. Zehe and Blöschl, 2004), we have established the following threshold relationship of the soil moisture content in the soil column $\left(\Theta_{\mathrm{E}}\right)$ and fissure connectivity $\left(C_{\text {fis }}\right)$ :

$$
\begin{aligned}
& C_{\mathrm{fis}, i}= \\
& \begin{cases}C_{\mathrm{fis}, \min }+\frac{\Theta_{\mathrm{E}, i}-\Theta_{\mathrm{E}, \mathrm{fc}}}{\Theta_{\mathrm{E}, \mathrm{sat}}-\Theta_{\mathrm{E}, \mathrm{fc}}}\left(C_{\mathrm{fis}, \max }-C_{\mathrm{fis}, \min }\right) & \text { for } \Theta_{\mathrm{E}, i} \geq \Theta_{\mathrm{E}, \mathrm{fc}} \\
C_{\mathrm{fis}, \min } & \text { for } \Theta_{\mathrm{E}, i}<\Theta_{\mathrm{E}, \mathrm{fc}}\end{cases}
\end{aligned}
$$

where $C_{\mathrm{fis}, i}$ and $\Theta_{\mathrm{E}, i}$ are fissure connectivity [-] and effective saturation of the matrix [-] at time step $i, C_{\text {fis,min }}$ and $C_{\text {fis, max }}$ are the minimal and maximal fissure connectivity, set to 0.1 and 0.9 , respectively. $\Theta_{\mathrm{E}, \mathrm{fc}}=\Theta_{\mathrm{E}, \mathrm{pF}=2.0}$ is effective saturation at the field capacity $[-]$ and $\Theta_{\mathrm{E}, \mathrm{sat}}=1$ (full saturation).

Introducing a direct relationship between fissure connectivity and soil moisture (Eq. 10) in the model will have an effect on the drainage capacity of the fissure network. With $C_{\text {fis }}>0$, the exchange of water in the fissure network between adjacent cells is enhanced, and the fraction of the water flux between the soil columns is controlled by the hydraulic conductivity of fissure network. In this way the dynamic nature of fissure connectivity, which influences the effectiveness of the drainage capacity of the fissures, is emphasized.

\section{Methodology}

\section{1 "Simple" landslide representation}

Model development and evaluation of the proof-of-concept are carried out using an idealised landslide representation.
The clone map consists of 30 rows by 175 columns and the grid size of $5 \times 5 \mathrm{~m}$. This gives a spatial domain of $875 \times 150 \mathrm{~m}$. The idealised digital elevation model (DEM) extends between $1725 \mathrm{~m}$ a.s.l. (toe of the landslide) and $2135 \mathrm{~m}$ a.s.l. (crown of the landslide), which corresponds to a planar slope of $25.1^{\circ}$.

The landslide body is delineated by an ellipse with a length of $800 \mathrm{~m}$ and a breadth of $90 \mathrm{~m}$. This allows us to account for the effect of converging and diverging topography. The depth of the slip plane along the major slope-parallel-axis of the ellipse is described by the arc of a circle passing through the crown and toe of the landslide body and its midpoint on the vertical, through the centre of the landslide. The maximum depth of the landslide is set to $8 \mathrm{~m}$, and it decreases towards the borders (Fig. 3a).

The soil parameters of each layer are set arbitrarily based on personal experience and measurements performed in clay shale landslide (Malet et al., 2005; Debieche et al., 2011; Krzeminska et al., 2011). Figure 3b shows the example of the distribution of soil parameters with depth for matrix and fissure fractions. The saturated hydraulic conductivity $\left(K_{\text {sat }}\right)$ was set to $4.1 \times 10^{-6}, 2.8 \times 10^{-6}$ and $2.4 \times 10^{-6} \mathrm{~m} \mathrm{~s}^{-1}$ for the matrix fraction, for layer 1, 2, and 3 respectively. For each layer, the $K_{\text {sat }}$ for fissure fraction was assumed to be 20 times higher than that of the matrix.

\subsection{Modelling strategy}

Four scenarios are evaluated:

- scenario 1 (no fissures) represents the landslide where no fissures are considered; 


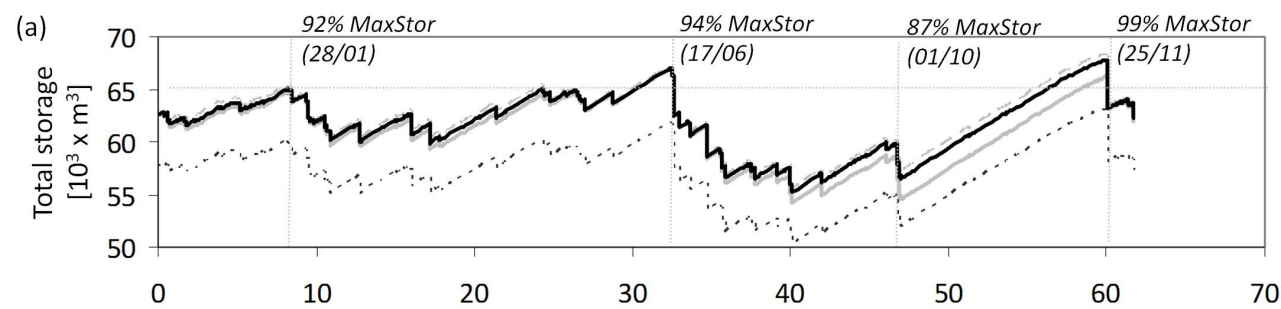

(b)

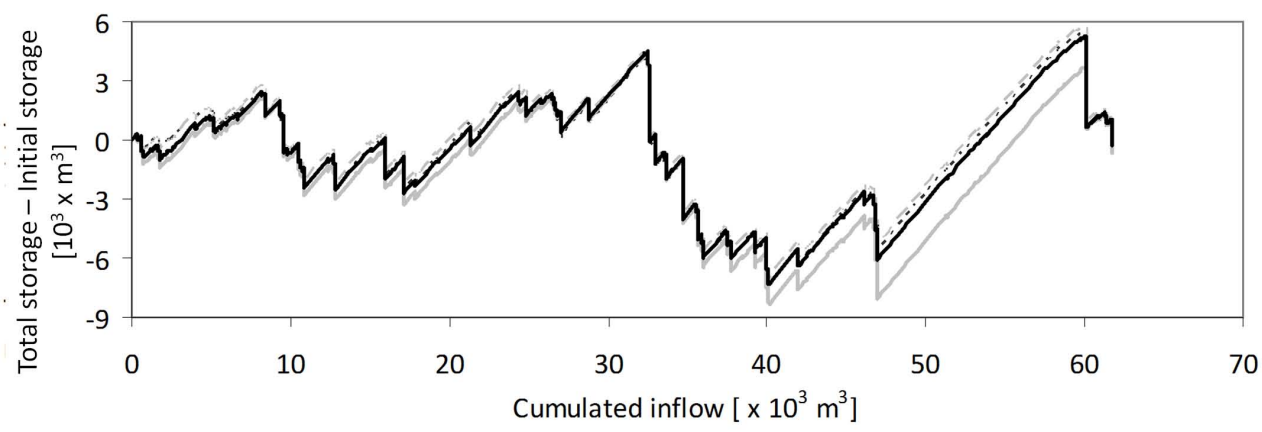

no fissures - - - disconnected fissures —- connected fissure

dynamic connectivity

Fig. 4. Variation in total storage during one-year simulation period expressed as a relationship between cumulative inflow (total rain volume) and changes in storage compared to initial condition.

- scenarios 2 and 3 (connected and disconnected fissures), where fissure properties are set to be constant over the simulation period, and fissure connectivity $\left(C_{\text {fis }}\right)$ is set to be $10 \%$ or $90 \%$ for "disconnected fissures" and "connected fissures" scenario respectively;

- scenario 4 (dynamic connectivity), scenario where the dynamic characteristic of fissure connectivity is applied.

Each model run is performed for one calendar year with the use of the same meteorological forcing (rain intensity, air temperature, incoming short wave radiation and relative humidity), generating a dynamic equilibrium of $470 \mathrm{~mm}$ of precipitation and around $1200 \mathrm{~mm}$ of potential evaporation. Snow accumulation was inhibited, by keeping the air temperature above freezing point, for the snow cover calculations. Moreover, the vegetation cover was not considered in the model.

The initial conditions (distributed groundwater level and soil moisture) were determined by spinning up the model with the "no fissures" scenario: the total initial storage of the landslide equals $91 \%$ of its storage capacity. The same initial conditions (determined for "no fissures" scenario) were applied for all the scenarios. The bedrock is considered to be non-permeable, and thus no percolation is lost across the lithic contact $(\mathrm{BC}=0)$. In this way, the pre-defined bedrock topography (see Sect. 3.1) constitutes a no-flow boundary condition. The outflow from the landslide area is possible in the form of surface runoff at the toe of the landslide.

For scenarios 2, 3 and 4 (fissure scenarios), an equal distribution of fissures was assumed over the whole landslide.
An average fissure fraction was set to $0.30,0.20$ and 0.05 , and an average fissure aperture was set to be $0.20,0.10$ and $0.05 \mathrm{~m}$ for $1 \mathrm{st}, 2 \mathrm{nd}$ and $3 \mathrm{rd}$ layer respectively. It is important to stress that in the model, the geometry of the landslide remains constant during the simulation period, and therefore no mass displacement is considered. The scenarios have no influence on the mechanical material properties.

The outputs of the simulations were collated and compared with each other, in order to see the effect of the introduction of fissures and their connectivity on the hydrological behaviour of the landslide. To this end, the water balance components were calculated and compared between the different scenarios.

As a last step, a sensitivity analysis was performed on the effect of the parameterisation of the matrix on the simulated hydrology. One parameter was perturbed in consecutive model run. Furthermore, a detailed sensitivity analysis of the fissure fraction parameterisation and fissure connectivity was performed to quantify whether the introduction of dynamic fissure behaviour is relevant, or if similar hydrological responses could be obtained with adapted hydraulic parameterisation of the fissure system.

\section{Simulation results}

\subsection{General water balance components of a landslide}

Table 1 shows the annual water balance components of four modelled scenarios. The initial conditions of each scenario 


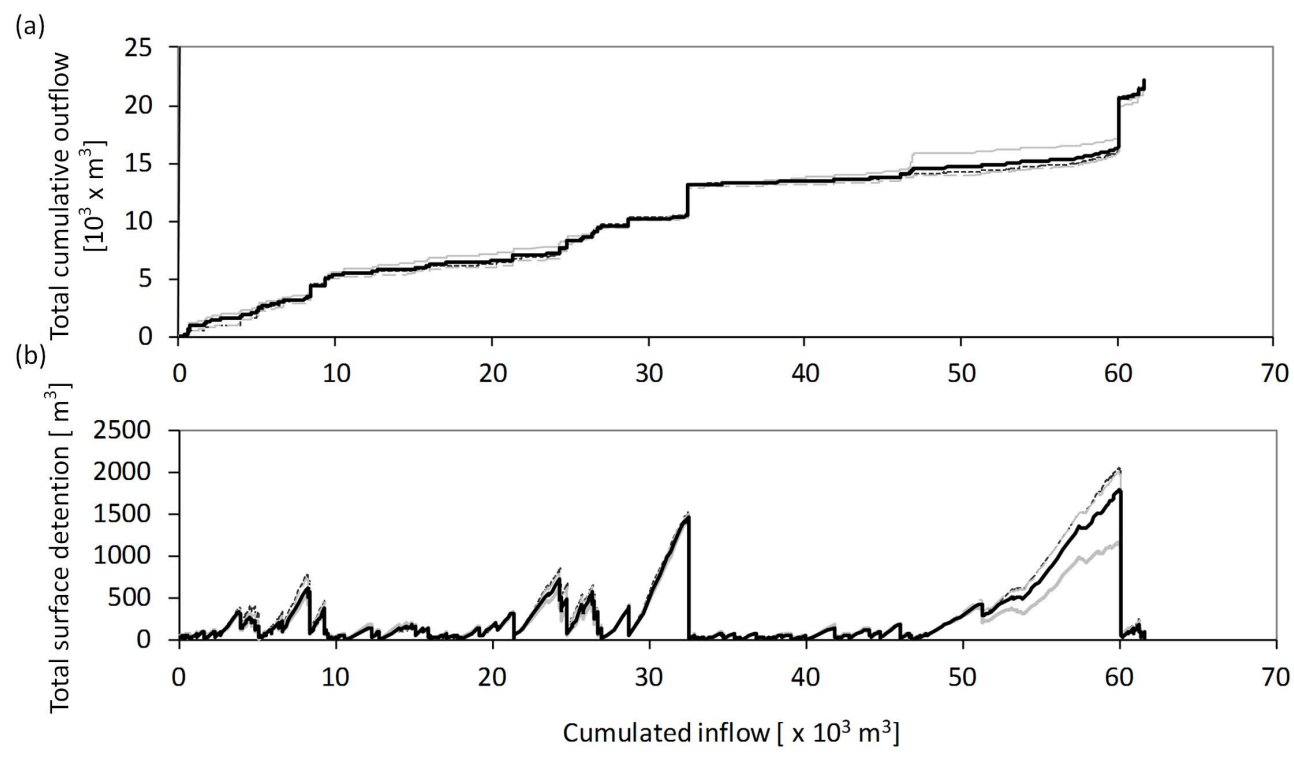

-------- no fissures - - - disconnected fissures — connected fissures — dynamic connectivity

Fig. 5. Variation in total cumulative outflow and total surface detention during one-year simulation period expressed in relationship to cumulative inflow (total rain volume).

have the same groundwater levels, soil moisture content and surface detention. Consequently, the total storage at the start of the simulation period is different for the "no fissures" scenario and the other three scenarios (the same groundwater levels but different porosities because of the introduction of the fissure network).

In general, there are only small differences in the water balance. The majority of the input (rain water) leaves the system as evaporation: between $64.7 \%$ of rain volume for the "no fissures" scenario and $65.7 \%$ of the rain volume for the "connected fissures" scenario. The relatively high evaporation rate for all of the scenarios is the effect of wet initial conditions (initial water storage in the landslide equals $91 \%$ of total available storage capacity) and maintenance of high water level in the lower part of the landslide due to predefined bedrock topography.

Over the simulation, the total volume of water stored within the system (including surface detention) decreases for all but the "disconnected fissures" scenario. The highest difference ( $1.1 \%$ of the total volume of rain) is observed for the "connected fissures" scenarios. Figure 4a shows the variation in total storage in relation to cumulative inflow (total volume of precipitation). The difference in total storage between the "no fissures" scenario and the other three scenarios, is the consequence of introducing fissures as a fraction of the landslide material with higher porosity. The same initial groundwater level and soil moisture content but higher porosity results in higher total storage values. However, when looking at the relative changes in total storage, with regard to initial conditions, one can see that the dynamics of total storage of "no fissures" and "disconnected fissures" are almost equal
(Fig. 4b). The overall behaviour of the system is very similar for all the scenarios with clear consecutive drying and wetting periods. The total storage of "disconnected fissures" is almost always the highest and that of "connected fissures" the lowest. The exceptions are the wet periods with total storage of the landslide more than $90 \%$ of its storage capacity (MaxStor). During these periods the simulated total storages are the same for all fissure scenarios.

Figure 5 shows cumulative outflow from the modelled area and surface detention over the landslide area in relation to cumulative inflow. There are very small absolute differences in the total cumulative outflow between the scenarios: total cumulative outflow equal to $35.9 \%, 35.4 \%, 35.2 \%$ of total rain volume for "dynamic fissures" scenario, "connected fissures" scenario and "disconnected fissures" respectively. This is the effect of pre-defined bedrock topography and no-flow boundary conditions that allow water outflow from the landslide in the form of surface runoff only and limit the variation of the outflow volume between scenarios. However, Fig. 5a shows that during the wetting periods the highest outflow is observed with "connected fissures" and during the drying periods the highest outflow is observed with "dynamic fissures". The outflow observed with "disconnected fissure" scenario is always the lowest. Consequently, the average surface detention, observed within landslide area is the lowest for the "connected fissures" scenario $\left(58.3 \mathrm{~m}^{3}\right)$, moderate for "dynamic connectivity" scenario $\left(63.0 \mathrm{~m}^{3}\right)$ and the highest for "disconnected fissures" and "no fissures" scenarios (72.6 and $75.4 \mathrm{~m}^{3}$ respectively). During the wet periods observed differences between the scenarios are negligible. 
Table 1. Annual water balance components of four modelled scenarios, calculated for whole spatial domain.

\begin{tabular}{lrrrr}
\hline & $\begin{array}{r}\text { No } \\
\text { fissures }\end{array}$ & $\begin{array}{r}\text { Disconnected } \\
\text { fissures }\end{array}$ & $\begin{array}{r}\text { Connected } \\
\text { fissures }\end{array}$ & $\begin{array}{r}\text { Dynamic } \\
\text { connectivity }\end{array}$ \\
\hline $\begin{array}{l}\text { Total storage at the start of simulated } \\
\text { period }\left[\mathrm{m}^{3}\right]\end{array}$ & 57618 & 62571 & 62571 & 62571 \\
$\begin{array}{l}\text { Total input (precipitation-evaporation) } \\
{\left[\mathrm{m}^{3}\right]}\end{array}$ & 61681 & 61681 & 61681 & 61681 \\
$\begin{array}{l}\text { Total storage at the end of simulated } \\
\text { period }\left[\mathrm{m}^{3} \text { ] }\right.\end{array}$ & 57431 & 62682 & 61877 & 62277 \\
$\begin{array}{l}\text { Change in total storage over the } \\
\text { simulation period }\left[\mathrm{m}^{3}\right]\end{array}$ & -187 & 111 & -694 & -294 \\
Total outflow $\left[\mathrm{m}^{3}\right]$ & 21933 & 21696 & 21816 & 22114 \\
\hline
\end{tabular}

\subsection{Spatial and temporal differences in groundwater level}

The timing and duration of near saturation is an important aspect for landslide (re-)activation. Figure 6 shows the total amount of days (during the one-year simulation period) with total saturation (groundwater level reaching the soil surface). Clear differences between the scenarios can be seen. The average number of days with saturation is $121,134,152$ and 128 days per cell for scenarios 1 to 4 respectively. While the average number of days with saturation for "no fissures" and "dynamic connectivity" is very similar, the spatial distribution of the storage (saturation) is different: much less saturation is observed in the upper part of the landslide when accounting for dynamic connectivity of fissures. The results of the "connected fissures" scenario are strongly affected by pre-defined bedrock topography and converging water flow paths. Faster drainage propagates water downslope, and vertically converging flow paths result in accumulation of the water in the lower part of the landslide.

It is interesting to compare the results presented in Fig. 6 with Fig. 7 showing the number of unstable cells $\left(f_{\mathrm{s}}<1\right)$ observed per time step. The average number of unstable cells observed in the scenarios where fissures are implemented is always higher than the one for "no fissures" scenario. The "disconnected fissures" and "connected fissures" scenarios present two extreme behaviours. This is the effect of an increase ("disconnected fissures") or decrease ("connected fissures") of the soil column weight ( $\left.W_{\text {fis }}, W_{\text {mat }}\right)$ and pore pressure due to different water distribution within the landslide.

Figure 8a shows an example of modelled groundwater levels from toe to crown along the landslide for six days during the one-year simulation periods. Figure 9 presents an example of the modelled groundwater level fluctuations for four points located along the landslide profile (see Fig. 3a). In the case of "connected fissures", water entering the fissure network is drained out of the landslide by fissures that provide continuous areas of high transmissivity. The total lateral saturated water flow $\left(Q_{\text {sat }}\right)$, which represents lateral drainage

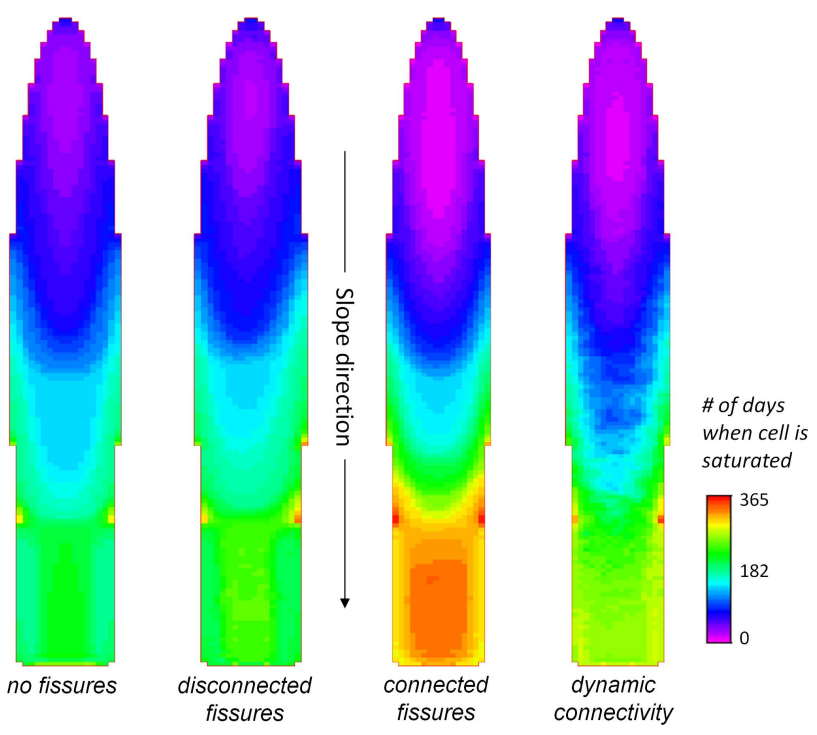

Fig. 6. The total number of days during one-year simulation period that full saturation was found.

within the landslide system (flow between cells), is approximately 1.6 times higher than in the case of the "no fissures" scenario, and $56 \%$ of this water is flowing through the fissure network. As a consequence, a general decrease of the groundwater level is found (Figs. 8 and 9b-d). Conversely, the model configuration with "disconnected fissures" creates areas with very high storage capacities, but with slower lateral exchange between cells. In this way, the groundwater table remains at a higher level compared to the "no fissures" and "connected fissures" scenarios. The total lateral saturated flow $\left(Q_{\text {sat }}\right)$, in the case of "disconnected fissures", is 1.3 times higher compared to the "no fissures" scenario, and approximately $30 \%$ of this flow occurs between the fissure fraction of one cell and matrix fraction of another cell, or between fissure fractions of the cells.

The groundwater level simulated with the "dynamic connectivity" scenario is a combination of the modest fluctuations observed for the "disconnected fissures" scenario and 


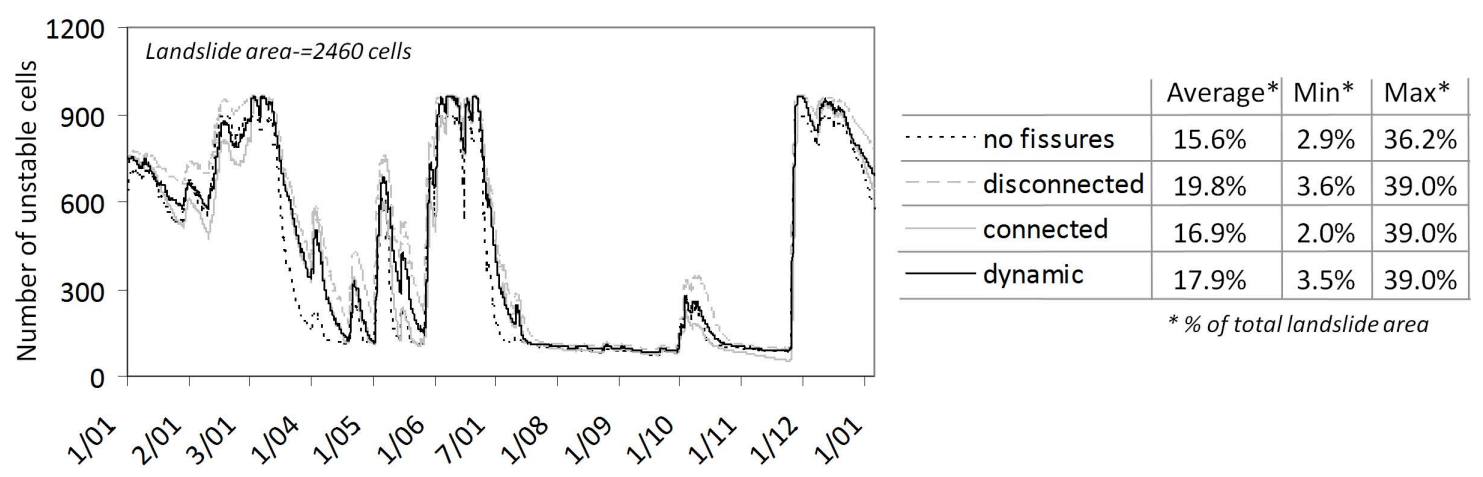

Fig. 7. The number of unstable cells $\left(f_{\mathrm{s}}<1\right)$ per time step, simulated with different scenarios.

the larger groundwater level fluctuation observed for that of "connected fissures". Fissure connectivity changes in time and space (Fig. 8b) according to the relationship defined with Eq. (9). However, the higher the total storage of the landslide is, the smaller the observed differences in groundwater level are between the scenarios (Fig. 8a).

At the lower part of the landslide (Fig. 9e), the groundwater behaviour depends on parallel flow paths (planar) and also converging flow paths (vertical). The simulation results show that this is especially important if a large volume of water can be transported from upslope via fast flow through a well-connected fissure system (the "connected fissures" scenario). Therefore, in the lower part of the landslide, the highest groundwater level is observed when the "connected fissures" scenario is implemented

There are significant differences between the scenarios in the timing of when saturation is reached (Fig. 9). The highest groundwater level is observed first for "disconnected fissures" or "no fissures", then "dynamic connectivity" and lastly the "connected fissures" scenario. The exception is the lowest part of the landslide (Fig. 9e) where, in case of the "connected fissures" scenario, most of the water accumulates, and thus groundwater level is the highest.

When looking at the exchange fluxes between the fissure and matrix fraction, clear differences between scenarios are visible. The absolute total exchange fluxes $(\Gamma)$ between fissure and matrix fractions $\left(\Gamma_{\mathrm{Sat}, \mathrm{FM}}+\Gamma_{\mathrm{Sat}}, \mathrm{MF}+\Gamma_{\text {Unsat, } \mathrm{FM}}\right)$ for "dynamic connectivity" equal $79 \%$ of the total observed for "connected fissures" and $130 \%$ of the one observed for "disconnected fissures". The same relation is observed when comparing unsaturated $\left(\Gamma_{\text {Unsat, }}\right.$ FM $)$ and saturated $\left(\Gamma_{\mathrm{Sat}}, \mathrm{FM}+\Gamma_{\mathrm{Sat}}, \mathrm{MF}\right)$ exchange fluxes separately. For all scenarios the saturated exchange fluxes $\left(\Gamma_{\mathrm{Sat}, \mathrm{FM}}+\Gamma_{\mathrm{Sat}, \mathrm{MF}}\right)$ are around $50-55 \%$ of total exchange fluxes. However, there are significant differences in flux directions. The ratio between the total amount of water flowing from the fissure fraction into the matrix fraction $\left(\Gamma_{\mathrm{Sat}}, \mathrm{FM}\right)$ and the total amount of water flowing from the matrix fraction into the fissure fraction $\left(\Gamma_{\mathrm{Sat}}, \mathrm{MF}\right)$ are 1.23, 1.12 and 0.95 for "disconnected fissures", "dynamic connectivity" and "connected fissures", respectively. The results of exchange fluxes analysis show that there are limited differences in piezometric head in matrix and fissure network for "disconnected fissures". They also show that, in the case of "connected fissures", these differences are getting bigger and that that groundwater level in the matrix is in general higher than the one in the fissure. The "dynamic connectivity" scenario is a combination of two extreme scenarios.

\subsection{Sensitivity analysis}

In general, the sensitivity analysis of the model is in line with the one presented by Van Beek (2002) and Malet et al. (2005). The porosity ( $\left.n_{\text {mat }}, n_{\text {fis }}\right)$ and saturated hydraulic conductivity ( $\left.K_{\text {sat,mat }}, K_{\text {sat,fis }}\right)$ are the parameters with the largest influence on the hydrological model (modelled storage). This is not surprising, since those two parameters control the soil moisture percolation with depth, groundwater recharge and saturated lateral flow. Changing these two parameters by adding or subtracting $25 \%$ and $50 \%$ of the absolute values for the porosity and $50 \%$ and $100 \%$ of the absolute values for for saturated hydraulic connectivity (for both matrix and fissure fractions at one time) results in maximal $10 \%$ (for $n$ ) or $12 \%$ (for $K_{\text {sat }}$ ) variation in modelled storage. There is an obvious strong positive relationship between changes in soil porosity, for both matrix and fissure fractions, and both saturated and unsaturated storages. In the case of changes in $K_{\text {sat }}$, the average total storage is almost constant, but an increase in $K_{\text {sat }}$ results in an increase in unsaturated storage in both fissure and matrix fraction and a decrease in corresponding saturated storages.

A more detailed sensitivity analysis of the fissure fraction parameterisation and fissure connectivity was performed to quantify whether the introduction of dynamic fissure behaviour is relevant, or if similar hydrological responses could be obtained with adapted hydraulic parameterisation of the fissure system. Figure 10 shows the results of the sensitivity analyses by plotting the number of days a cell was saturated as a function of the hydraulic parameterisation of the fissures 


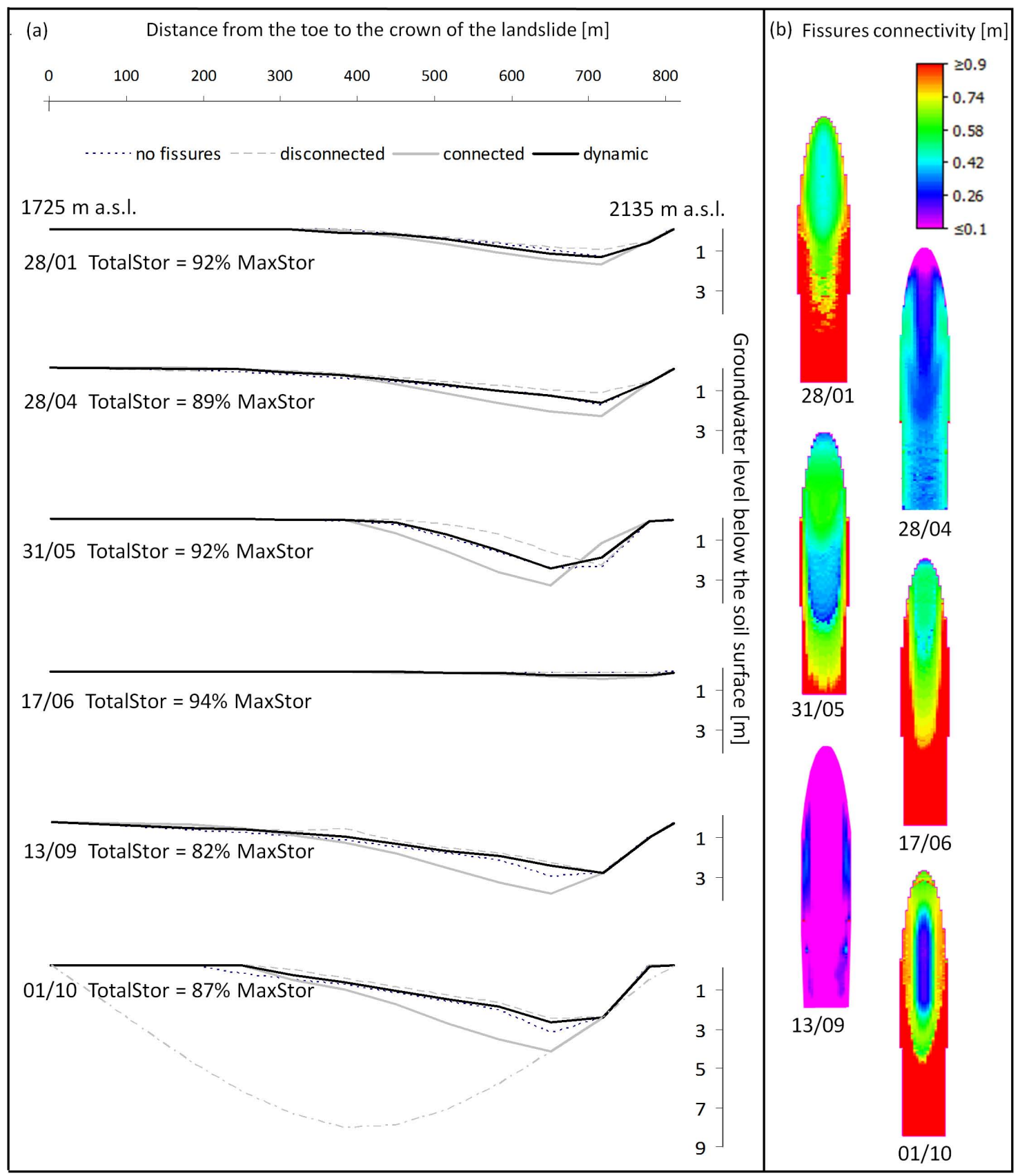

Fig. 8. (a) Modelled groundwater levels along the landslide profile (major axes of the ellipse); $x$-axis represents the distance from the toe of the landslide $(0 \mathrm{~m})$ to the crown $(800 \mathrm{~m})$. (b) The distribution of fissure connectivity over the landslide area, corresponding to these groundwater levels and observed total storages. The light grey line, present in the last profile of sub-figure (a), represents the bedrock depth. Please note the exaggeration of the vertical scale.

$\left(K_{\text {sat,fis }}, n_{\text {fis }}\right)$. The reference plot (the "dynamic connectivity" scenario) is located in the upper right corner of the sensitivity matrix. Moving along the x-axis $K_{\text {sat,fis }}$ decreases, while moving along y-axis the porosity of fissure fraction $\left(n_{\text {fis }}\right)$ decreases. The lower left plot represents the situation of matrix flow only, as the saturated hydraulic connectivity and porosity of matrix and fissure fractions are the same. Note, however, that this is not similar to the "no fissures" scenario, as the air entry value and shape factor of soil water retention curve are also defined separately for the fissure fraction. Figure 10 shows that when decreasing $K_{\text {sat,fis, }}$, the upper part of the landslide exhibits more saturation, meaning that the groundwater levels remain higher in the upper part of the landslide area. This is due to the reduced drainage capacity of 
(a)

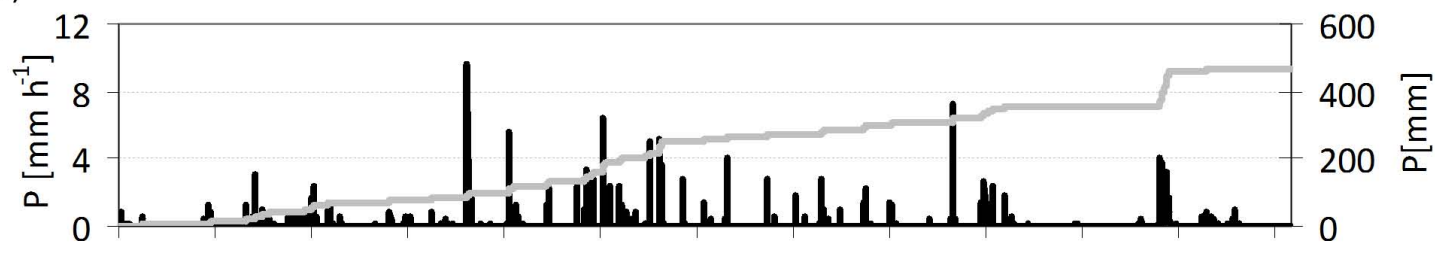

(b)

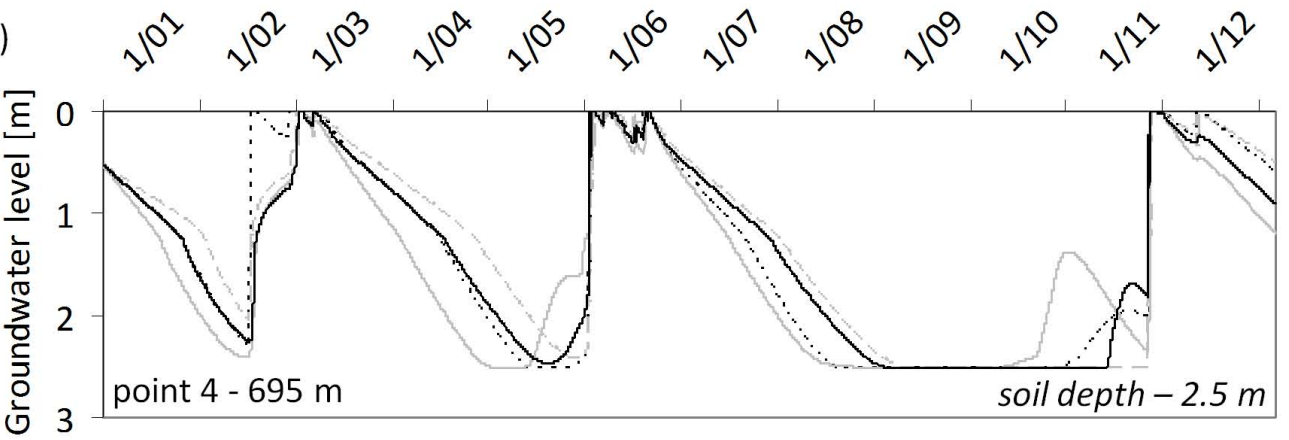

(c)

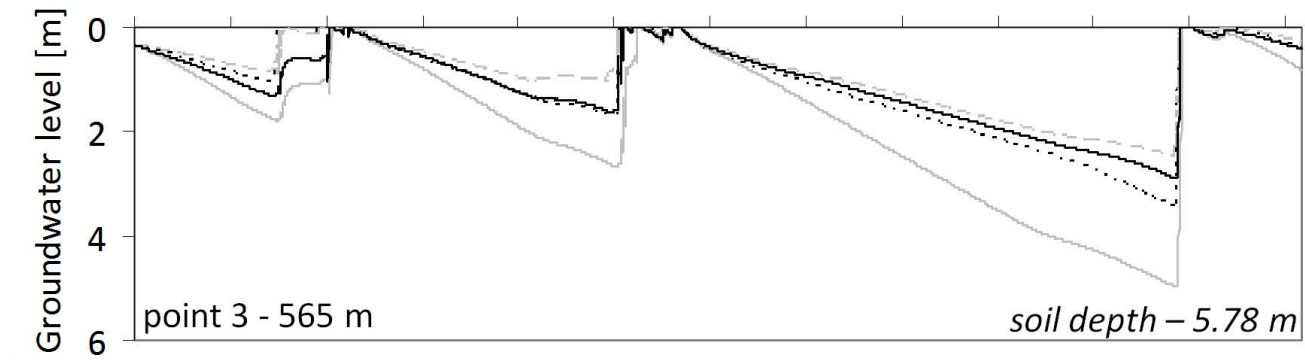

(d)

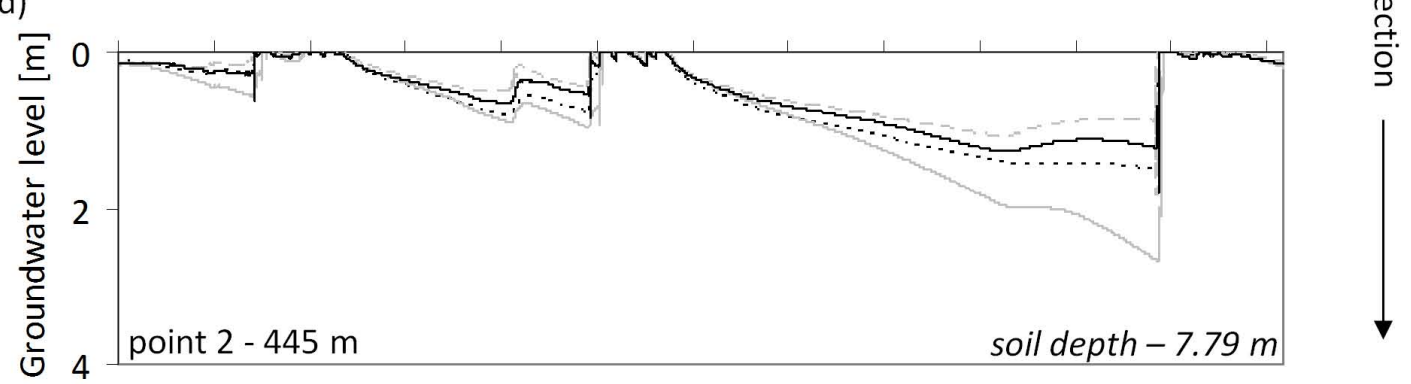

(e)

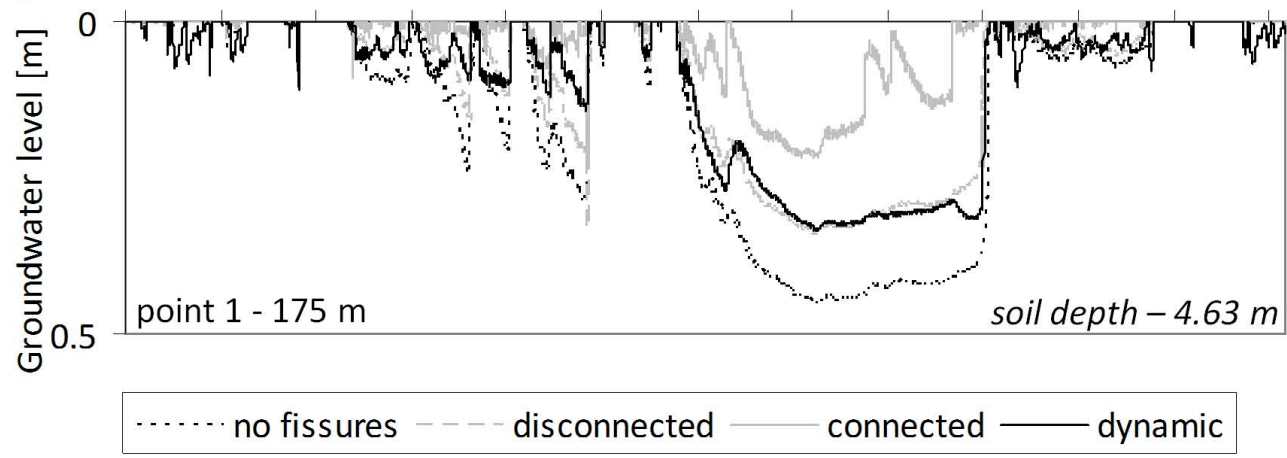

Fig. 9. Time series results of the one-year simulation period: (a) precipitation; (b-e) examples of groundwater level fluctuations observed in four points located along the landslide profile (major axes of the ellipse) from the toe $(0 \mathrm{~m})$ to the scarp $(800 \mathrm{~m})$ of the landslide. See Fig. $8 \mathrm{a}$ for the landslide profile and Fig. 3a for specific location of four points. 


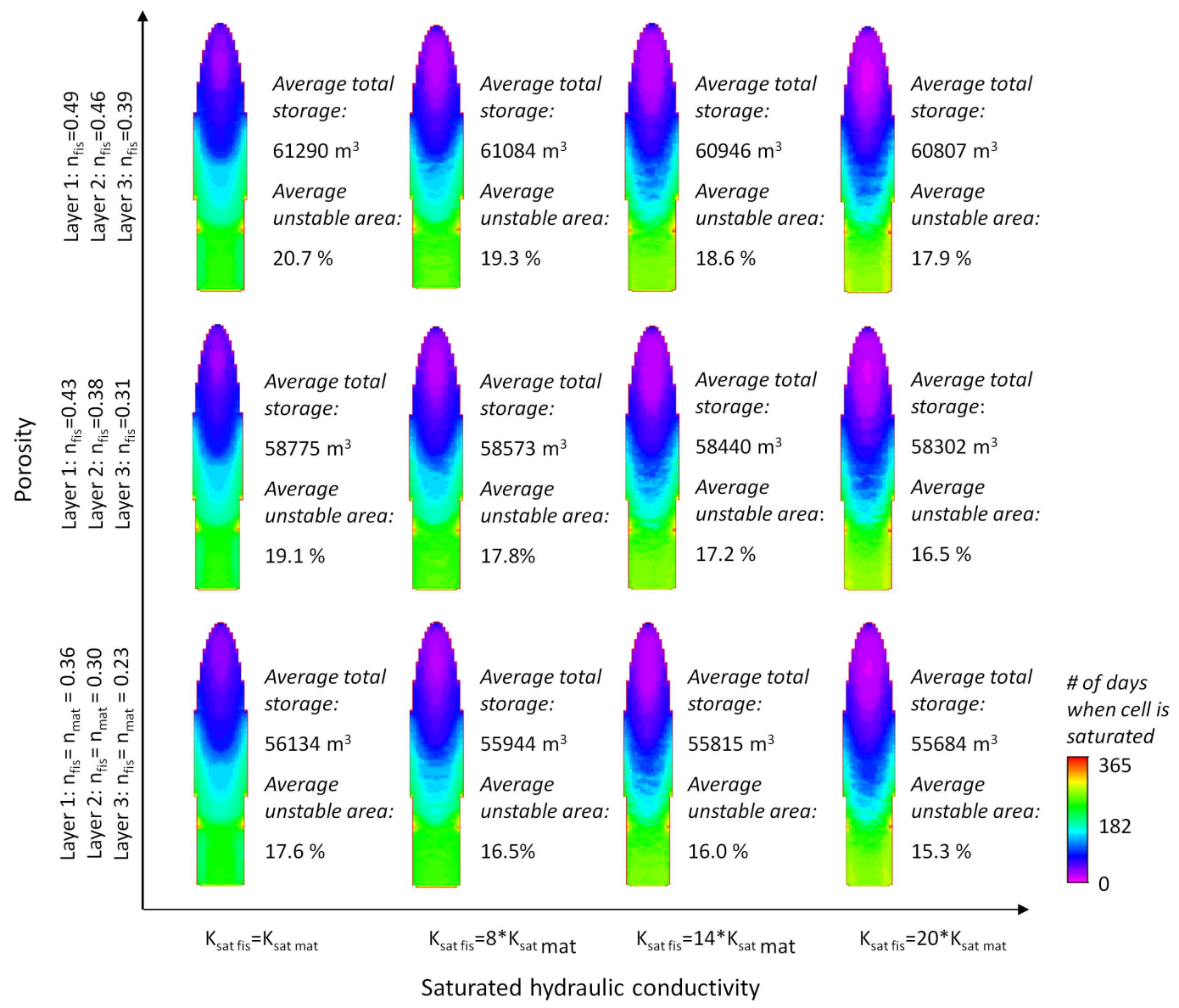

Fig. 10. Sensitivity analysis of the model for changes in the fissure parameterisation. The unstable area is the area of all cells where $f_{\mathrm{s}}<1$. The plot located in upper right corner is the reference plot - the "dynamic connectivity" scenario. Moving to the left along the x-axis, $K_{\text {sat,fis }}$ decreases, while moving down along y-axis, the $n_{\text {fis }}$ decreases.

the fissure network. On the other hand, when $n_{\text {fis }}$ decreases (getting closer to $n_{\text {mat }}$ ) there are limited differences in water distribution within the landslide; however, the percentage of the unstable area decreases. This is the result of decreased infiltration capacity of the fissures: less water flows to the deeper layers, and therefore less water moves from the fissures to the matrix. Consequently, it results in a slower groundwater table rise.

Figure 11a shows the results coming from the four reference scenarios: "no fissures", "disconnected fissures", "connected fissures" and "dynamic connectivity" scenarios. Figure $11 \mathrm{~b}$ shows the effect of the influence of a fissure network with different fissure connectivities (from 10 to $90 \%$ ) that are set constant over the simulation period. The last panel (Fig. 11c) presents the simulation results for the "connected fissures" scenario but with different lower saturated hydraulic permeability for the fissure fraction $\left(K_{\text {sat,fis }}\right)$. Figure 11 shows that the results of the simulation using constant fissure connectivity differ clearly from the one performed with dynamic fissure connectivity, despite changes in the fissure fraction characteristics: fissure connectivity (Fig. 11b) and fissure hydraulic permeability (Fig. 11c). Comparing the results of Fig. 11b with the "dynamic connectivity" scenario of Fig. 11a, it can be seen that constant fissure connectivity results in more water in the lower part of the landslide and gives a larger average unstable area for similar average total storage. The saturated permeability of the fissures (Fig. 11c) basically affects the drainage capacity, independent of the connectivity fraction.

The general conclusion that can be drawn from the sensitivity analysis is that the results obtained with "dynamic connectivity" scenario cannot be reached using effective hydraulic parameterisation of the fissure fraction with constant connectivity. The "dynamic connectivity" scenario seems to be able to accommodate more water in the system, causing less instability. 

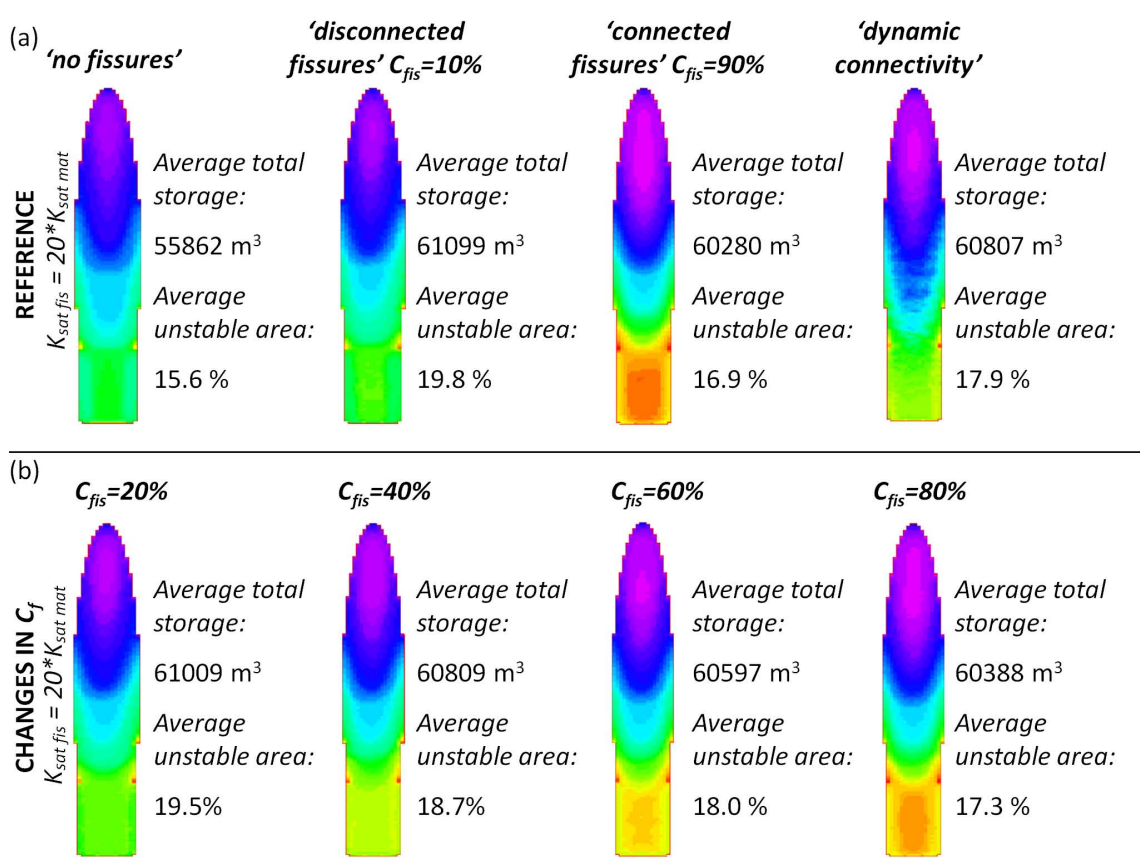

(c) $K_{\text {sat, fis }}=5 * K_{\text {sat }, \text { mat }} \quad K_{\text {sat, fis }}=8 * K_{\text {sat, mat }} \quad K_{\text {sat, fis }}=11 * K_{\text {sat, } m a t} \quad K_{\text {sat, fis }}=14 * K_{\text {sat, } m a t}$

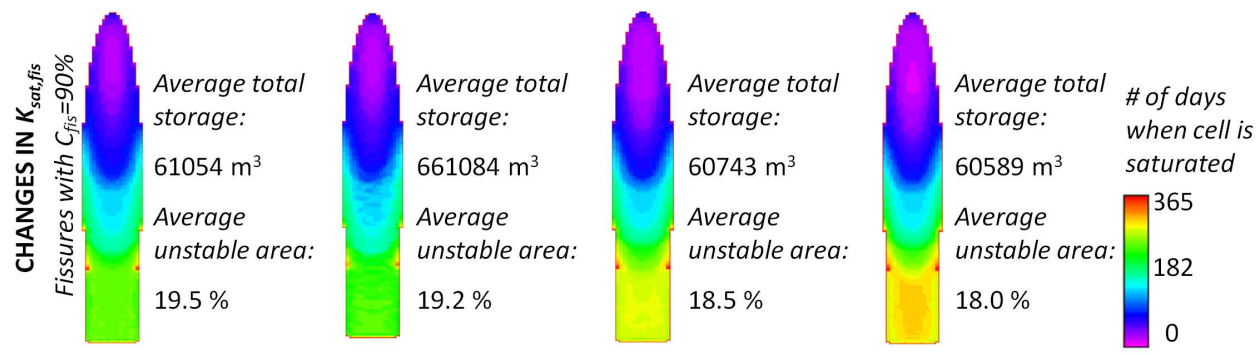

Fig. 11. Sensitivity analysis of the model for changes in conceptualisation of fissure connectivity: (a) is the reference panel - the "no fissures", "disconnected fissures", "connected fissures" and "dynamic connectivity" scenarios; (b) changing fissure connectivity $\left(C_{\text {fis }}\right)$ for the simulation with fissures included ( $C_{\mathrm{fis}}$ is constant over the simulation period); (c) changing saturated hydraulic conductivity for the "connected fissures" scenario.

\section{Discussion and conclusions}

This research aimed to study the importance of preferential fissure flow for landslide hydrological behaviour at the field scale, with a conceptual modelling approach using the Storage and Redistribution of Water on Agricultural and Revegetated Slopes model (STARWARS), which is a distributed model coupling hydrological and stability dynamics (Van Beek, 2002). The results highlight that fissure connectivity and fissure permeability are important parameters of the fissure network. Both of these parameters can change the water distribution within the landslide and influence the timing and the duration of the periods of elevated pore pressure conditions.

The presented conceptual model of fissure flow is based on dual-permeability approach. The use of dual-permeability approach for preferential fissure flow modelling allows incorporating knowledge about commonly observed features of a fissure network, such as retaining their own porosity and soil moisture content (Malet et al., 2005), matrix - fissure interaction (Van Beek and Van Asch, 1999) as well as providing dynamically changing natural preferential flow paths (Weiler and McDonnell, 2007). This way of simulating preferential fissure flow seems more realistic when compared to the simplistic preferential flow representation in a form of bypassing flow (Malet et al., 2005) or modified hydraulic conductivity function only (Mulungu et al., 2005; Zhang et al., 2006). Moreover, the use of GIS-based PCRaster programming language gives the opportunity to account for spatial heterogeneity of soil hydrological properties and distributed nature of the fissure systems.

The results presented in this paper are in agreement with previous studies: presence of fissures increases the vertical infiltration rate and influences storage capacity of the soil 
(McDonnell, 1990; Uchida et al., 2001). When a fissure network consists of disconnected fissures only, the storage capacity increases whereas outflow is impeded. This results in persistently high groundwater levels and less spatial variations across the landslide. A connected fissures network shows fast preferential drainage as the dominant process and thus results in a lower groundwater level. In this way, fissures and the dynamic variation in their connectivity control the distribution of soil pore water pressure, which is an important factor for initiation and reactivation of mass movement (Cameira et al., 2000; Uchida et al., 2001; Nobles et al., 2004). The results presented in this paper show that presence of fissures increases the overall stability of the landslide. However, it is important to stress that downslope converging flow paths (resulting from bedrock topography and no-flow boundary conditions) in combination with extended, well-connected fissure network result in the accumulation of the water from the upper part of the landslide in the lower part of the landslide. That can lead to very high groundwater level and negatively affect the stability of the toe of the landslide. This effect might also be observed in reality, depending on the geomorphology and topography of the valley and the geometry of the toe itself. However, it is necessary to have in mind that the fissure network defined in our study ( $F_{\text {fis }}=30 \%$ over the whole landslide area) is quite large and it would not often be that extensive in a real case study.

Introducing the dynamic fissure connectivity, dependent upon soil moisture content as earlier proposed for soil pipe networks (e.g. Nieber and Sidle, 2004), results in composite behaviour spanning the end members mentioned above. This range of hydrological responses under dry and wet conditions introduces stronger seasonality than static fissure connectivity. This is more similar to what is actually observed in nature. Furthermore, the analysis showed that dynamic fissure behaviour could not be mimicked using adjusted hydraulic parameterisation for the fissures. We recognize the difficulties in quantification of the dynamic fissure connectivity characteristics, but we believe this research has shown that it is worthwhile to include dynamic fissure characteristics into hydrological modelling of the landslide.

Our research indicates the need for further studies in the direction of measurement of fissure characteristics and monitoring of their variation over time. It would be worthwhile to look at orientation of fissures. This would allow us to better define and constrain the relationship between fissure connectivity and saturation degree of the soil. It may also shed light on other relationships, i.e. between fissure volume and differential soil movement within a landslide.

Acknowledgements. This work was supported by the European Commission within the Marie Curie Research and Training Network "Mountain Risks: from prediction to management and governance" (2007-2010, Contract MCRTN-035798, http://www.unicaen.fr/mountainrisks). The authors are grateful to the three anonymous reviewers for their help in improving the quality of the manuscript. We also would like to thank Maia Ibsen and colleagues from Kingston University (London) for revising the English of the manuscript.

Edited by: E. Zehe

\section{References}

Beckers, J. and Alila, Y.: A model of rapid preferential hillslope runoff contributions to peak flow generation in a temperate rain forest watershed, Water Resour. Res., 40, W03501, doi:10.1029/2003WR002582, 2004.

Beven, K. and Germann, P.: Macropores and water flow in soils, Water Resour. Res., 18, 1311-1325, 1982.

Bogaard, T. A.: A state-dependent ground water recharge model for landslide research, which simulates preferential flow, in: Proceedings of the 9th IAEG Congress,Durban, South Africa, 1620 September, 2002.

Bogaard, T. A. and van Asch, T. W. J.: The role of the soil moisture balance in the unsaturated zone on movement and stability of the Beline landslide, France, Earth Surf. Proc. Land., 27, 1177-1188, 2002.

Bouma, J.: Using morphometric expressions for macropores to improve soil physical analyses of field soils, Geoderma, 46, 3-11, 1990.

Brand, E. W., Dale, M. J., and Nash, J. M.: Soil pipes and slope stability in Hong Kong, Q. J. Eng. Geol., 19, 301-303, 1986.

Brolsma, R.: Effect of climate change on temperate forest ecosystems, PhD Thesis, University of Utrecht, Netherlands, 2010.

Brooks, S. M., Crozier, M. J., Preston, N. J., and Anderson, M. G.: Regolith stripping and the control of shallow translational hillslope failure: application of a two-dimensional coupled soil hydrology-slope stability model, Hawke's Bay, New Zealand, Geomorphology, 45, 165-179, 2002.

Cameira, M. R., Ahuja, L., Fernando, R. M., and Pereira, L. S.: Evaluating field-measured soil hydraulic properties in water transport simulations using the RZWQM, J. Hydrol, 236, 78-90, 2000.

Cappa, F., Guglielmi, Y., Merrien-Soukatchoff, V., Mudry, J., Bertrand, C., and Charmoille, A.: Hydromechanical modeling of a large moving rock slope inferred from slope levelling coupled to spring long term hydrochemical monitoring: example of the La Clapière landslide (Southern Alps, France), J. Hydrol., 291, 67-90, 2004.

Debieche, T.-H., Bogaard, T. A., Marc, V., Emblanch, C., Krzeminska, D. M., and Malet, J.-P.: Hydrological and hydrochemical processes observed during a large-scale infiltration experiment at the Super-Sauze mudslide (France), Hydrol. Process., doi:10.1002/hyp.7843, 2011.

Fannin, R. J., Jaakkola, J., Wilkinson, J. M. T., and Hetherington, E. D.: Hydrologic response of soils to precipitation at Carnation Creek, British Columbia, Canada, Water Resour. Res., 36, 14811494, 2000.

Farrel, D. and Larson, W.: Modeling of the pore structure of porous media, Water Resour. Res., 8, 699-705, 1972.

Gerke, H. H.: Preferential flow descriptions for structured soils, J. Plant Nutr. Soil Sc., 169, 382-400, 2006.

Iverson, R. M.: Landslide triggering by rain infiltration, Water Resour. Res., 36, 1897-1910, 2000. 
Jarvis, N. J.: A review of non-equilibrium water flow and solute transport in soil macropores: principles, controlling factors and consequences for water quality, Eur. J. Soil Sci., 58, 523-546, 2007.

Kosugi, K., Uchida, T., and Mizuyama, T.: Numerical calculation of soil pipe flow and its effect on water dynamics in a slope, Hydrol. Process., 18, 777-789, 2004.

Krzeminska, D. M., Bogaard, T. A., Debieche, T.-H., Marc, V., Ponton, J., and Malet, J.-P.: Quantitative analysis of preferential flow during small scale infiltration tests on an active mudslide, French Alps, in: "Landslide Processes" International Conference, Strasbourg, France, 6-7 February, 2009.

Krzeminska, D. M., Steele-Dunne, S. C., Rutten, M. M., Bogaard, T. A., and Sailhac, P.: High resolution temperature observations to monitor hydrological features in reworked clay shales slopes, Hydrol. Process., online first: doi:10.1002/hyp.7980, 2011.

Kuriakose, S. L., van Beek, L. P. H., and van Westen, C. J.: Parameterizing a physically based shallow landslide model in a data poor region, Earth Surf. Proc. Land., 34, 867-881, 2009.

Malet, J.-P., van Asch, Th. W. J., van Beek, R., and Maquaire, O.: Forecasting the behaviour of complex landslides with a spatially distributed hydrological model, Nat. Hazards Earth Syst. Sci., 5, 71-85, doi:10.5194/nhess-5-71-2005, 2005.

McDonnell, J. J.: The influence of macropores on debris flow initiation, Q. J. Eng. Geol. Hydroge., 23, 325-331, doi:10.1144/GSL.QJEG.1990.023.04.06, 1990.

Miller, D. J. and Sias, J.: Deciphering large landslides: linking hydrological groundwater and stability models through GIS, Hydrol. Process., 12, 923-941, 1998.

Millington, R. J. and Quirk, J. P.: Permeability of porus media, Nature 183, 387-388, 1959.

Mulungu, D. M. M., Ichikawa, Y., and Shiiba, M.: A physically based distributed subsurface-surface flow dynamics model for forested mountainous catchments, Hydrol. Process., 19, 39994022, 2005.

Nieber, J. L. and Sidle, R. C.: How do disconnected macropores in sloping soils facilitate preferential flow, Hydrol. Process., 24, 1582-1594, doi:10.1002/hyp.7633, 2010

Nobles, M. M., Wilding, L. P., and McInnes, K. J.: Pathways of dye tracer movement through structured soils on a macroscopic scale, Soil Sci., 169, 229-242, 2004.

Noguchi, S., Tsuboyama, Y., Sidle, R. C., and Hosoda, I.: Morphological characteristics of macropores and the distribution of preferential flow pathways in a forested slope segment, Soil Sci. Soc. Am. J., 63, 1413-1423, 1999.

Pierson, T. C.: Soil pipes and slope stability, Q. J. Eng. Geol., 16, $1-15,1983$.

Sidle, R. C., Tsuboyama, Y., Noguchi, S., Hosada, I., Fujieda, M., and Shimizu, T.: Stormflow generation in steep forested headwaters: a linked hydrogeomorphic paradigm, Hydrol. Process., 14, 369-385, 2000.

Sidle, R. C., Noguchi, S., Tsuboyama, Y., and Laursen, K.: A conceptual model of preferential flow systems in forested hillslopes: evidence of self-organization, Hydrol. Process., 15, 1675-1692, doi:10.1002/hyp.233, 2001.

S̆imünek, J., N. J. Jarvis, van Genuchten, M. T., and Gardenas, A.: Review and comparison of models for describing nonequilibrium and preferential flow and transport in the vadose zone, J. Hydrol., 272, 14-35, 2003.
Skempton, A. W.: The long-term stability of clay slopes, Geotechnique, 14, 95-102, 1964.

Trojan, M. and Linden, D.: Micro relief and rainfall effects on water and solute movement in earthworm burrows, Soil Sci. Soc. Am. J., 56, 727-733, 1992.

Tsuboyama, Y., Sidle, R. C., Noguchi, S., and Hosada, I.: Flow and transport through the soil matrix and macropores of hillslope segment, Water Resour. Res., 30, 879-890, 1994.

Uchida, T., Kosugi, K., and Mizuyama, T.: Effects of pipeflow on hydrological process and its relation to landslide: a review of pipeflow studies in forested headwater catchments, Hydrol. Process., 15, 2151-2174, 2001.

van Asch, Th. W. J., Hendriks, M. R., Hessel, R., and Rappange, F. E.: Hydrological triggering conditions of landslides in varved clays in the French Alps, Eng. Geol., 42, 239-251, 1996.

van Asch, Th. W. J., van Beek, L. P. H., and Bogaard, T. A.: Problems in predicting the mobility of slow-moving landslides, Eng. Geol., 91, 46-55, 2007.

van Beek, L. P. H.: Assessment of the influence of changes in land use and climate on landslide activity in a Mediterranean environment, PhD Thesis, University of Utrecht, Netherlands, 2002.

van Beek, L. P. H. and van Asch, T. W. J.: A combined conceptual model for the effects of fissure-induced infiltration on slope stability, in: Process Modelling and Landform Evolution, Lect. Notes Earth Sci., 78, 147-167, doi:10.1007/BFb0009716, 1999.

van Schaik, N. L. M. B.: Spatial variability of infiltration patterns related to site characteristics in a semi-arid watershed, Catena, 78, 36-47, 2009.

van Schaik, N. L. M. B.: The role of macropore flow, from plot to catchment scale. A study in a semi-arid area, $\mathrm{PhD}$ Thesis, University of Utrecht, Netherlands, 2010.

van Schaik, N. L. M. B., Schnabel, S., and Jetten, V. G.: The influence of preferential flow on hillslope hydrology in a semi-arid watershed (in the Spanish Dehesas), Hydrol. Pocess., 22, 38443855, 2008.

van Westen, C. J., van Asch, T. W. J., and Soeters, R.: Landslide hazard and risk zonation: why it is so difficult?, B. Eng. Geol. Envir., 65, 167-184, 2005.

Weiler, M. and McDonnell, J. J.: Conceptualizing lateral preferential flow and flow networks and simulating the effects on gauged and ungauged hillslopes, Water Resour. Res., 43, W03403, doi:10.1029/2006WR004867, 2007.

Weiler, M. and Naef, F.: An experimental tracer study of the role of macropores in infiltration in grassland soils, Hydrol. Process., 17, 477-493, 2003.

Wu, W. and Sidle, R. C.: A distributed slope stability model for steep forested basins, Water Resour. Res., 31, 2097-2110, 1995.

Zehe, E. and Blöschl, G.: Predictability of hydrologic response at the plot and catchment scales - the role of initial conditions, Water Resour. Res., 40, W10202, doi:10.1029/2003WR002869, 2004.

Zhang, G. P., Savenije, H. H. G., Fenicia, F., and Pfister, L.: Modelling subsurface storm flow with the Representative Elementary Watershed (REW) approach: application to the Alzette River Basin, Hydrol. Earth Syst. Sci., 10, 937-955, doi:10.5194/hess10-937-2006, 2006. 